https://doi.org/10.11646/zootaxa.4461.2.9

http://zoobank.org/urn:lsid:zoobank.org:pub:3014B9EB-8CC9-4E16-9224-776E3F78B193

\title{
Description of the larva and pupa of Limnephilus hamifer Flint 1963 (Trichoptera, Limnephilidae) from Costa Rica
}

\author{
MONIKA SPRINGER ${ }^{1,2,4} \&$ JENNY BERMÚDEZ-MONGE ${ }^{3}$ \\ ${ }^{1}$ Escuela de Biología, Museo de Zoología, Universidad de Costa Rica, San Pedro de Montes de Oca, San José, Costa Rica, 11501- \\ 2060 \\ ${ }^{2}$ Centro de Investigaciones en Ciencias del Mar y Limnología (CIMAR); San Pedro de Montes de Oca, San José, Costa Rica \\ ${ }^{3}$ Universidad de Ciencias Médicas UCIMED, San José, Costa Rica. E-mail: bermudezmj@ucimed.com \\ ${ }^{4}$ Corresponding author. E-mail: monika.springer@ucr.ac.cr
}

\begin{abstract}
The larva and pupa of Limnephilus hamifer Flint 1963 are described and illustrated for the first time. The description is based on material collected and reared from the Cerro de la Muerte mountain range in Costa Rica, and from additional specimens deposited at the Zoological Museum of the University of Costa Rica. The distribution of this species is restricted to high mountain areas of Costa Rica and Panamá and constitutes the most southern distribution of the genus on the American continent.
\end{abstract}

Key words: Central America, Neotropics, caddisflies, immature stages, taxonomy

\section{Resumen}

Se describe e ilustra por primera vez la larva y pupa de Limnephilus hamifer Flint 1963. La descripción está basada en material recolectado y criado del macizo montañoso Cerro de la Muerte de Costa Rica, además de material depositado en la colección del Museo de Zoología de la Universidad de Costa Rica. La distribución de esta especie está restringida a las zonas montañosas de Costa Rica y Panamá y constituye la distribución más sureña del género en el continente Americano.

Palabras claves: Centroamérica, Neotrópico, tricópteros, estadios inmaduros, taxonomía

\section{Introduction}

Limnephilidae is one of the most species rich families of Trichoptera with 10 genera known from the Neotropics (Holzenthal et al. 2007; Holzenthal \& Calor 2017). The large genus Limnephilus Leach 1815 is distributed throughout the Holarctic Region, extending southward into Central America (Holzenthal \& Calor 2017) where species occur in cold waters at higher altitudes (Ruiter 1995). Only two species of this genus have been reported from Central America: L. hamifer Flint 1963 and L. maya Flint 1967. Limnephilus maya has been collected from Mexico, Guatemala, and Honduras (Ruiter 1995), while L. hamifer was described from Costa Rica (Flint 1963) and was also found recently in northern Panama (Armitage et al. 2015).

Limnephilid larvae can generally be found in lentic habitats, such as small vernal pools, swamps, lakes, or slow moving reaches of rivers and streams (Flint et al. 1999). Their cases vary in shape and material, such as plant fragments, seeds, empty mollusk shells, or mineral matter (Wiggins 1996). Plant material is the principal food, although occasionally they also feed on dead animal matter. Larvae have been described for species from Europe, Asia, and North America (e.g., Lepneva 1971; Wallace 1980; Wiggins 1996; Wallace et al. 2003; Waringer \& Graf 2011; Ruiter et al. 2013; Graf et al. 2015), but larvae for neither of the Central American species have yet been associated with their adult stages. In this paper, we describe the larva and pupa of L. hamifer from reared material, 
collected in the Cerro de la Muerte mountain range in Costa Rica, and from additional specimens from the Zoological Museum.

\section{Materials and methods}

Limnephilus larvae were collected on 9 September 2015 in small ponds and slow-flowing channels along the Río Macho, in oak-forest habitats within the private reserve "Selva Madre" (km 60 Interamerican Highway; $2600 \mathrm{~m}$ a.s.l.; $9^{\circ} 40^{\prime} 45.8^{\prime} \mathrm{N},-83^{\circ} 52{ }^{\prime} 35.1$ 'W) at Cerro de la Muerte (San José Province). The specimens were collected with hand nets and final instar larvae were reared to adults in the laboratory to ensure the association between larval and adult stages. Adult species identity was verified through examination of male genitalia and by comparing with species descriptions given by Ruiter (1995).

Additional larval material from other collection sites, deposited in the Aquatic Entomology Collection at the Museum of Zoology at the University of Costa Rica (MZUCR) was examined. For these specimens, molecular genetic sequence data were used to support the larval-adult association (included in iBol Trichoptera barcode of life, available at: http://trichopterabol.org/), in addition to morphological features. Distribution data of adult collections were obtained from the University of Minnesota Entomology data base (UMSP).

Terminology for larval and pupal morphology, and setal nomenclature, follows that of Wiggins (1996) and Waringer \& Graf (2011). An Olympus SZX16 dissection microscope was used for descriptions and drawings. All specimens are deposited in the Museum of Zoology at the University of Costa Rica (MZUCR).

\section{Description of final instar larva and pupa of Limnephilus hamifer}

Material examined: SAN JOSÉ, Cerro de la Muerte, Selva Madre, Río Macho, 2600 m a.s.l., 09.ix.2015 (M. Springer \& J. Bermúdez): 11 field-collected last-instar larvae, six of those reared in the laboratory to adults. Additional larval material examined (MZUCR): ALAJUELA: Volcán Poás, Laguna Botos, 2700 m a.s.l., vii.1994 (M. Springer); CARTAGO: Estación Biol. Cerro de la Muerte, Laguna La Muerte, 3100 m a.s.l., 17-19.x.1998 (F. Mora, C. Obando); same, but 18.xi.1999 (M. Springer); same, but 09.ii.2002 (R. Acosta), same, but 31.x.2009 (D. Salas); Cerro de la Muerte, las torres, Paramo, 3200 m a.s.l. viii.1997 (P. Hanson). HEREDIA: San Isidro, Montaña Pinacho, 1500 m a.s.l. vii.1995 (S. Shahroody); Vara Blanca, Cerro Chompipe, 2000 m a.s.l., 24.ix.2000 (L. Sandoval), same, but 07-08.xi.2002 (K. Nishida); Volcán Barva, 2500 m a.s.l., 20.viii.2016 (G. Rojas). SAN JOSÉ: Cerro de la Muerte, km 70, Paramo ponds, 3100 m a.s.l., ix.1996 (N. Franz); Los Santos, Quebrada Serrano, 2650 m a.s.l., 04.ix.2010 (F. Reyes); Perez Zeledón, Cerro Chirripó, lagos Las Morenas, 3500 m a.s.l., v.2017 (J. Picado).

Larva (Figs. 1-9). Body length (without case) 18-23 mm, width 35-40 mm ( $\mathrm{n}=7)$.

Head (Figs. 1-3): Width 1.3-1.5 mm $(\mathrm{n}=7)$. Dark to medium brown in colour with pale muscle attachment spots clearly visible. Labrum reddish with 8 transparent setae and with dense setal brush along most of anterolateral margins. Mandibles black, apical third lighter in colour, each with 4 apical teeth, inner margin with dense, golden, median setal brush, lateral base with 1 or 2 pale setae (Fig. 2). Head dorsally with primary setae only, as in Fig. 1. Posterior apex of frontoclypeus with pale triangular area. Ventral apotome longer than posterior ventral ecdysial line (Fig. 3); inner and outer areas of cardo black, with lighter area between them (Fig. 3).

Thorax (Fig. 4): Pronotum uniformly brown with distinct pale muscle attachment spots posteriorly; posterior margin elevated, heavily sclerotized, with pair of thin, black transverse stripes with lighter area between them or almost completely black. Transverse depression present on anterior third. Anterior margin with dense row of very fine, transparent setae. Mixture of thick black, long and short setae concentrated behind anterior margin and behind transverse depression. Proventer with two very small, dark lateral prosternites, separated from central prosternite, prosternite slightly darker in posterior half. Mesonotum uniformly brown, similar to pronotum, with distinct pale muscle attachment spots; pair of small darker pigmented areas midlaterally; posterior margin black, extending anteriorly on lateral margins to half their length. Mesonotal plates with dark setae of variable size in three primary setal areas. Mesosternum with irregular row of small, rounded, light brown sclerites along posterior margin. Metanotum with sclerites $s a 1, s a 2$ and $s a 3$ yellowish-brown, each with mixture of thick, long and short, dark setae; 
central membranous area between $s a 2$ sclerites with one pair of medium-sized, dark setae and few scattered, short dark setae. Meso- and metasterna each with one pair of short dark setae medially and one pair near base of each coxa. Coxopleurites light brown, each bearing several long, dark setae.
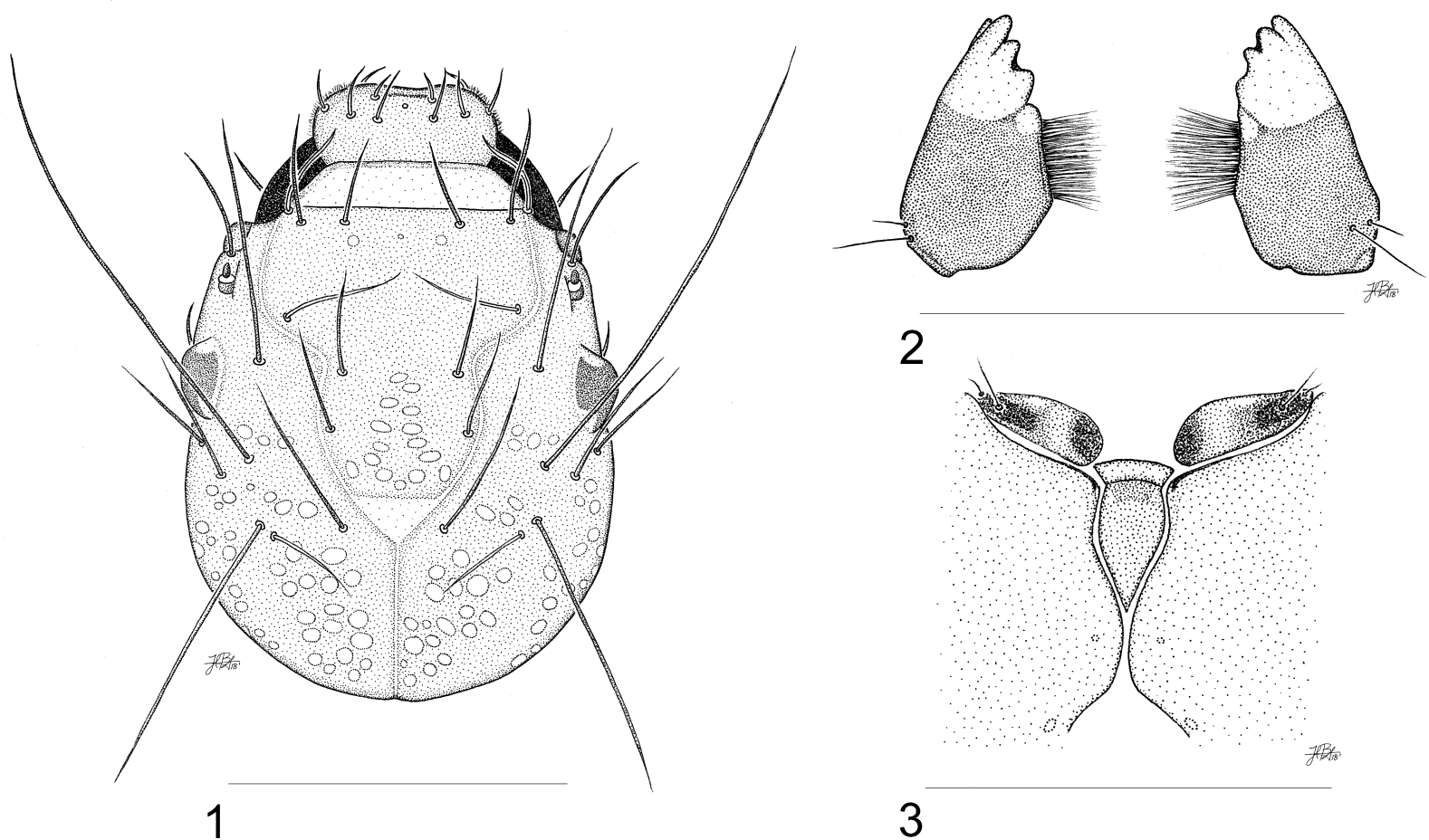

3

FIGURES 1-3. Limnephilus hamifer, fifth instar larva. 1, head, dorsal; 2, left and right mandibles; 3, ventral apotome. Scale bars: $1 \mathrm{~mm}$.

Legs (Figs. 5a-5c): Yellowish brown in colour with muscle attachment spots clearly visible on coxa and trochanter. Mesothoracic legs slightly longer than metathoracic legs. Each trochanter with ventrodistal setal brush and without additional setae on proximal section. Ventral comb row (ventral row of short pale spines) present on all legs, from posterior third of trochanter to posterior third of tarsus of each leg. Forfemora each with two strong ventral setae pale in colour, differing in length. Meso- and metafemora each with two long ventral setae contrasting in colour. Femora lacking additional face setae. Each tibia and tarsus with primary setae only. Tarsal claws each with short basal seta.

Abdomen (Figs. 6-8): Lateral fringes extending on each side from anterior borders of segment III to posterior borders of segment VIII. Gills present on segments II-VIII with position and number of filaments as in Table I. Abdominal segment I with well-developed dorsal, lateral, and ventral humps; setae present anterior and lateral of dorsal hump, and dorsal and ventral of lateral humps; venter with various small and medium-size dark setae in each sa3, and numerous small and medium-size dark setae on ventral hump (Fig. 6, sal and sa2 combined). Abdominal segments II-VII each with 2 dorsal primary $s a 2$ setae only. Segment VIII dorsally with posterior transverse row of alternating long and short setae, and other smaller setae sparsely distributed on dorsal surface (Fig. 7). Segment IX with dorsal sclerite yellowish to light brown, with 4 primary setae, additional small spiniform setae, and mediumsize dark setae distributed between them and extending laterally to membranous area (Fig. 7). Lateral sclerites of anal prolegs (Figs. 7, 8) each with 5 primary setae, additional short and medium-size dark setae, and about 10 yellowish stout spines (Fig. 8a); Anal proleg claws (Fig. 8b) light brown, darker apically, each with one accessory hook and 3 long dark dorsal setae and 4 medium-size dark ventral setae; basal sclerite of each anal claw with black dorsal border and 1 seta at anterolateral corner; lobes of anal prolegs ventrally each with 4 setae on soft cuticle on each side of anal slit. 

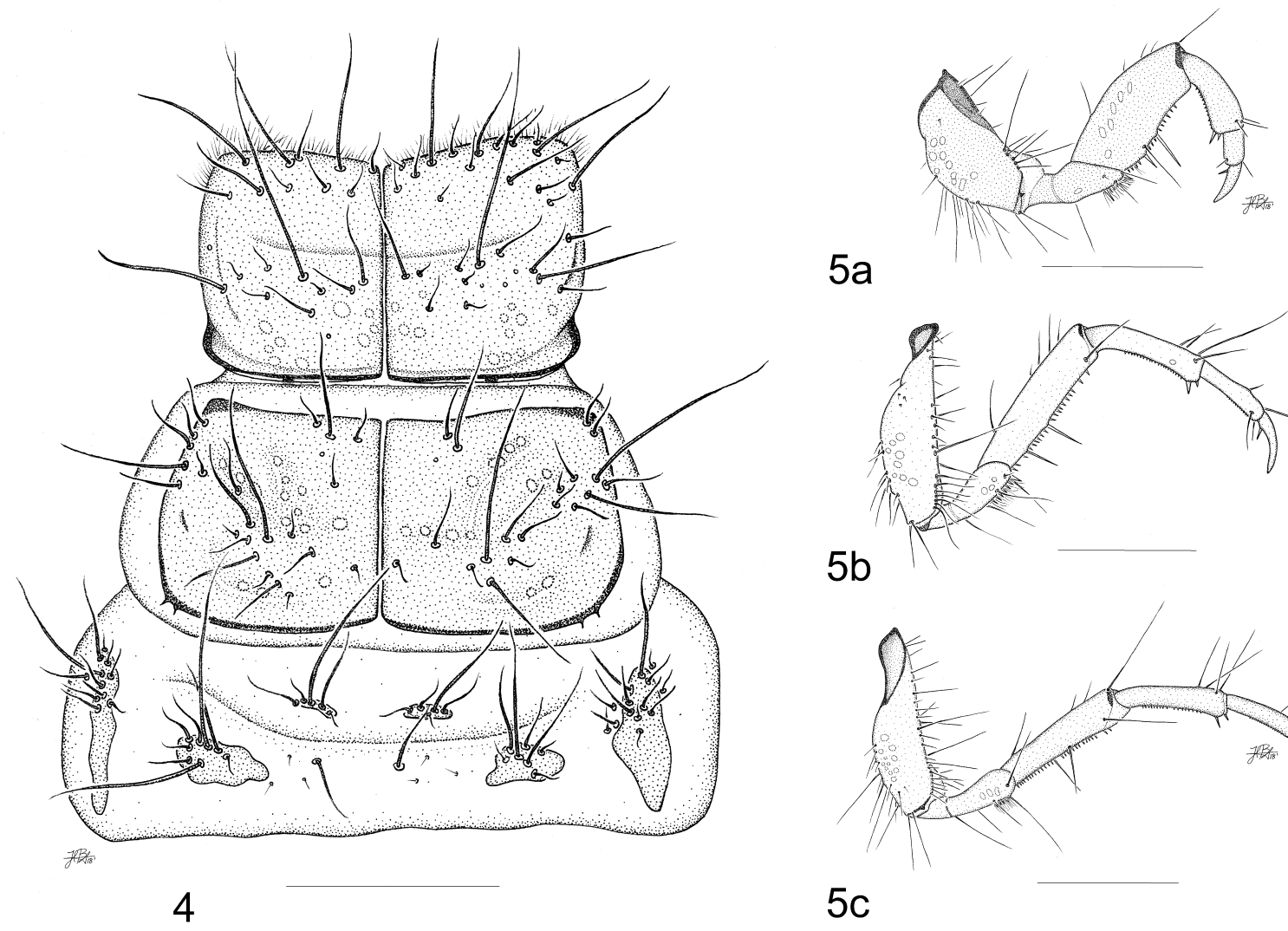

$5 a$
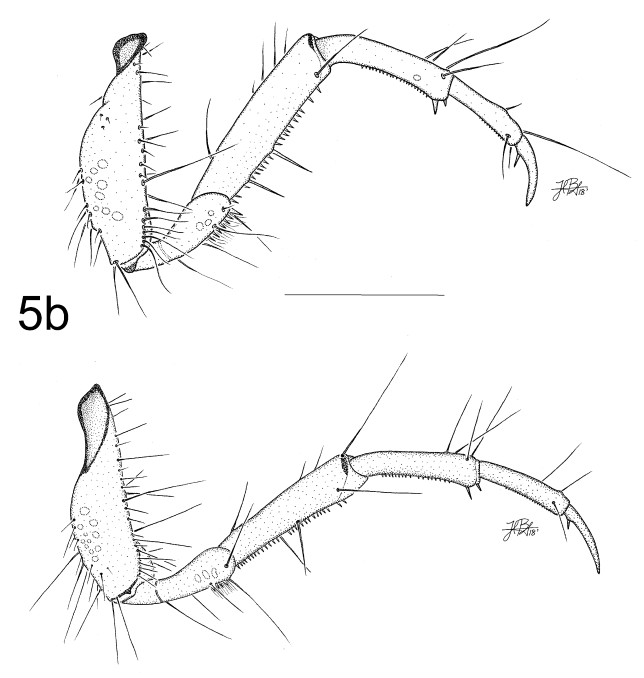

$5 c$

FIGURES 4-5. Limnephilus hamifer, fifth instar larva. 4, thorax, dorsal; 5a, right prothoracic leg, posterior; 5b, right mesothoracic leg, posterior; 5c, right metathoracic leg, posterior. Scale bars: $1 \mathrm{~mm}$.

TABLE 1. Number of filaments of tracheal gills on abdominal segments II-VIII of fifth instar larvae of Limnephilus hamifer. Positions abbreviated as: $\mathrm{A}=$ anterior, $\mathrm{D}=$ dorsal, $\mathrm{L}=$ lateral, $\mathrm{P}=$ posterior, $\mathrm{V}=$ ventral.

\begin{tabular}{llllllll}
\hline Gill & II & III & IV & V & VI & VII & VIII \\
\hline AD & $2-3$ & 3 & 3 & 3 & 3 & 3 & $2-3$ \\
PD & 3 & 3 & 3 & 3 & 3 & $3-2$ & 0 \\
ADL & 3 & 3 & 3 & $1-2$ & $0-2$ & 0 & 0 \\
PDL & 3 & $2-3$ & $1-2$ & $1-2$ & 1 & $0-1$ & 0 \\
AV & 3 & 3 & 3 & 3 & 3 & 2 & 1 \\
PV & 3 & 3 & 3 & 3 & 3 & 2 & 0 \\
\hline
\end{tabular}

Case (Figs. 9a, 9b): Length 17-23 mm, width 35-50mm $(\mathrm{n}=7)$; shape ranging from rather evenly contoured, slightly curved cylinder of rock and plant pieces to irregular and incorporating larger plant pieces arranged longitudinally. Posterior end open, not closed with silk.

Pupa (Figs. 10-13): Length 10-16 mm ( $\mathrm{n}=6$; males and females).

Head (Fig. 10): 3 pairs of setae on anterolateral margins of frontoclypeus, 2 pairs long and dark, 1 pair short and pale; 2 pairs of setae at frontal margins of eyes; 2 pairs of long dark setae on frontal region and 1 pair on vertex between antennae; 1 pair of short setae ventromedially on eye surface; 3 pairs of short setae dorsally on head, behind bases of antennae. Pale blotch present in frontoclypeal area. Anterior tentorial pits well marked. Each antenna with ventrolateral antennal tuft of 5-6 setae, dorsal antennal tuft of 9 setae. Labrum semicircular with 5 pairs of thick, rigid, long, apically hooked setae. Mandibles without teeth, each with base wide, apex acute, and 
with 2 thick dark basolateral setae. Maxillary palps each 3-segmented in male, 5-segmented in female. Labial palps each 3-segmented, short, reaching bases of forecoxae.

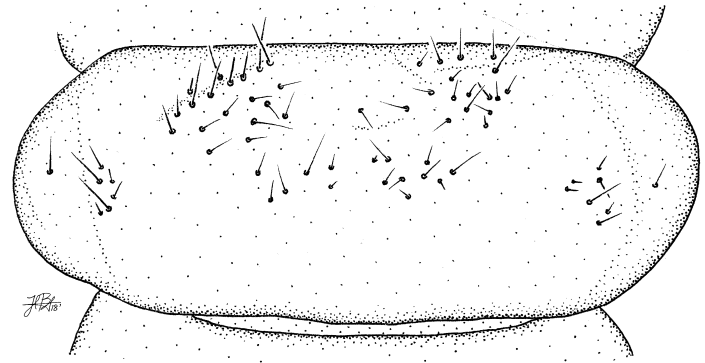

6

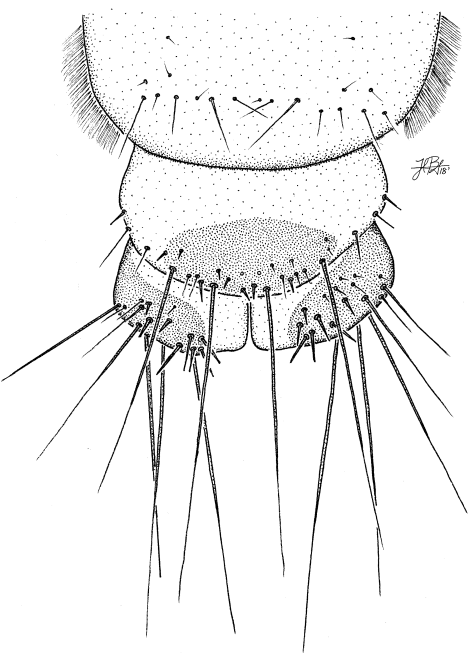

7

FIGURES 6-8. Limnephilus hamifer, fifth instar larva. 6, abdominal segment I, ventral; 7, abdominal segments VIII and IX with anal prolegs, dorsal; 8a, posterior end of abdomen, left lateral; 8b, left anal claw, left lateral. Scale bars: $1 \mathrm{~mm}$.

Thorax: Pronotum with 1 pair of dorsal setae, mesonotum with 1 anterior pair near median line and 2 pairs on central area, metanotum with 1 pair on central area. Legs long; thick, black setae present on all coxae, each forecoxa with 6 setae, middle coxa with 5 setae, and hind coxa with 1 seta; natatory setae long and fine, arranged in double row on tarsomeres $1-4$ of middle and hind legs. Wing pads reaching abdominal segment IV.

Abdomen (Figs. 11-13): Lateral fringes of long fine dark brown setae extending from final portion of segment $\mathrm{V}$ to end of segment VIII, where they merge posteroventrally. Dorsally, abdominal segment I with transverse striae and with 1 pair of anterior and 2 pairs of posterior submesal setae, segments II to VII each with 1 pair of short midlateral setae and 3 pairs of posterior submedian setae, segment VIII with 1 pair of short submedian setae, posterolateral margin with 4 pairs of long dorsal setae and 1 pair of long dorsal posterior submedian setae, mixed with some very short setae; segment IX with 3 pairs of long and 1 pair of short setae; segments II-IX each with 13 pairs of lateral setae and $1-5$ pairs of ventral setae. Segments II-VII mesally and posteriorly each with $1-3$ dorsolateral and ventrolateral pairs of tufts of branched, filamentous gills; segment VIII with only anterior dorsolateral and ventrolateral pairs of branched, filamentous gills. Anterior hook plates on segments III-VII round to elliptical, each bearing 2-3 small hooks; posterior plates on segment $\mathrm{V}$ transversely rectangular, each bearing 12-16 small hooks; number of hooks varying among individuals and between right and left plates of same individual (Fig. 12). Segment IX (Fig. 13) with tegument slightly sclerotized, pale brown, bearing several pairs of long dark dorsal and ventral setae and numerous small transparent setae; apical portion with longitudinal median depression, dorsally densely covered with small spines. Anal processes (Fig. 13) long, slender, cylindrical, with 
apical portions divergent; each bearing on dorsal surface 1 small seta basally and 1 small seta medially; apically with 2 subterminal setae on inner surface and row of very small dense spines.

Case (Figs. 9c, 9d): Last larval instar case modified for use as pupal case, with some additional plant material irregularly added. Anterior opening closed by silk and case fixed on substrate (leaves).

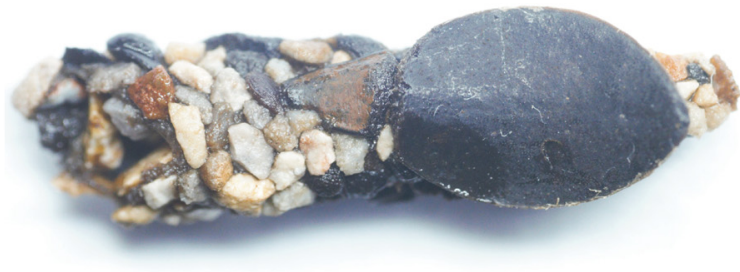

$9 \mathrm{a}$

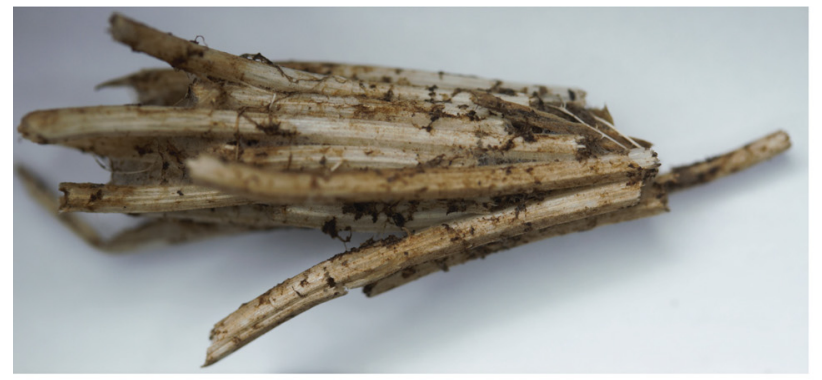

$9 \mathrm{c}$

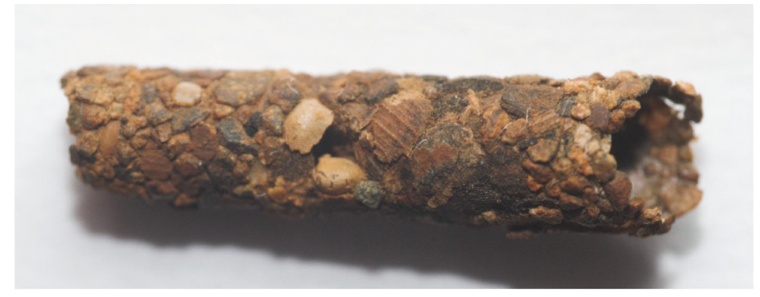

$9 \mathrm{~b}$

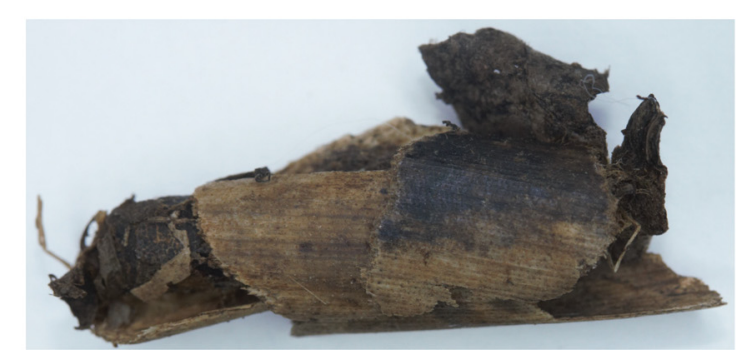

$9 \mathrm{~d}$

FIGURES 9A-D. Limnephilus hamifer, cases. 9a, 9b, fifth instar larval cases. 9c, 9d, pupal cases. Scale bars: $10 \mathrm{~mm}$.

Biology and habitat. Limnephilus hamifer larvae were found in small ponds and shallow, small, flowingwater pools in open areas as well as in forested sites. Pool bottoms were covered with detritus (mainly leaves). At one collection site, the water was brown due to humic acids. Water temperature was around $12^{\circ} \mathrm{C}(11 \mathrm{am})$.

Presently, no studies are available on the life cycle of this species, but collection dates of adults (February, July, September, November and December), and lack of pronounced seasonality in this area suggest that the flight period is year round. This is also supported by the fact that larvae can be found throughout the year and with overlapping generations, indicating that $L$. hamifer is multivoltine.

Local distribution. Limnephilus hamifer is restricted to high mountain areas, above $1500 \mathrm{~m}$ a.s.l., with natural vegetation, such as cloud and oak forest, and paramo (Fig. 14).

Comparison with other species. Since larvae of the vast majority of North American Limnephilus species remain undescribed, no comprehensive comparison or key can yet be presented. Ruiter et al. (2013) provided distinguishing characters, images and a key to 18 species from the Churchill area in Canada.

As stated and shown by Wiggins (1996) and Ruiter et al. (2013), colour patterns of the head are an important distinguishing character, with many species bearing patterns of contrasting colours. Limnephilus hamifer belongs to the group of species with a rather uniformly brownish head with visible muscle spots, such as $L$. ademus, $L$. alaicus, L. argenteus, L. diphyes, L. fenestratus, L. frijole, L. major, L. perpusillus, L. picturatus, and L. sericeus. Within this group, $L$. ademus, alaicus, major have lateral accessory setae on the mesofemur, which are absent in $L$. hamifer. Of the remaining species, L. hamifer can be distinguished by the following combination of characters: anterior ventral apotome about half the length of the ecdysial suture, head with small pale areas limited to frontoclypeal area, and pale muscle spots.

Finally, it is important to note that within Central America, the only other species which could overlap in distribution with L. hamifer (presently known only from Costa Rica and Panama), is L. maya, for which the larval and pupal stages remain unknown. 


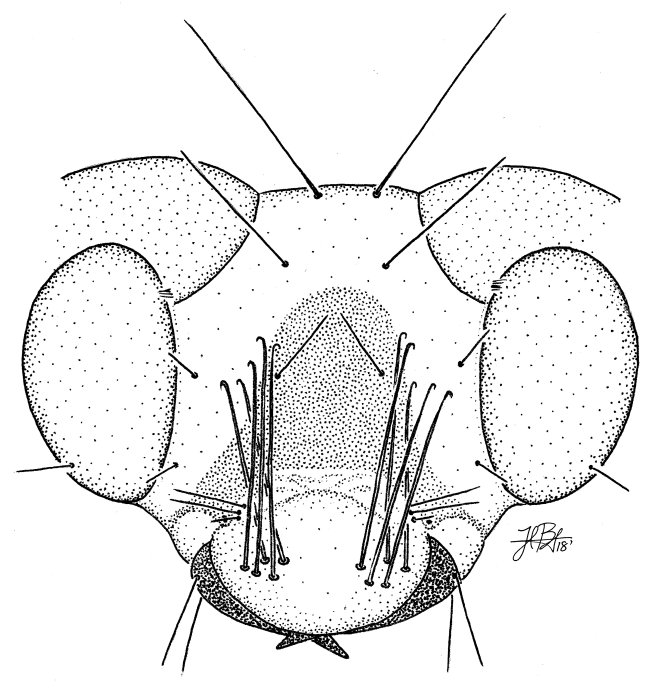

10

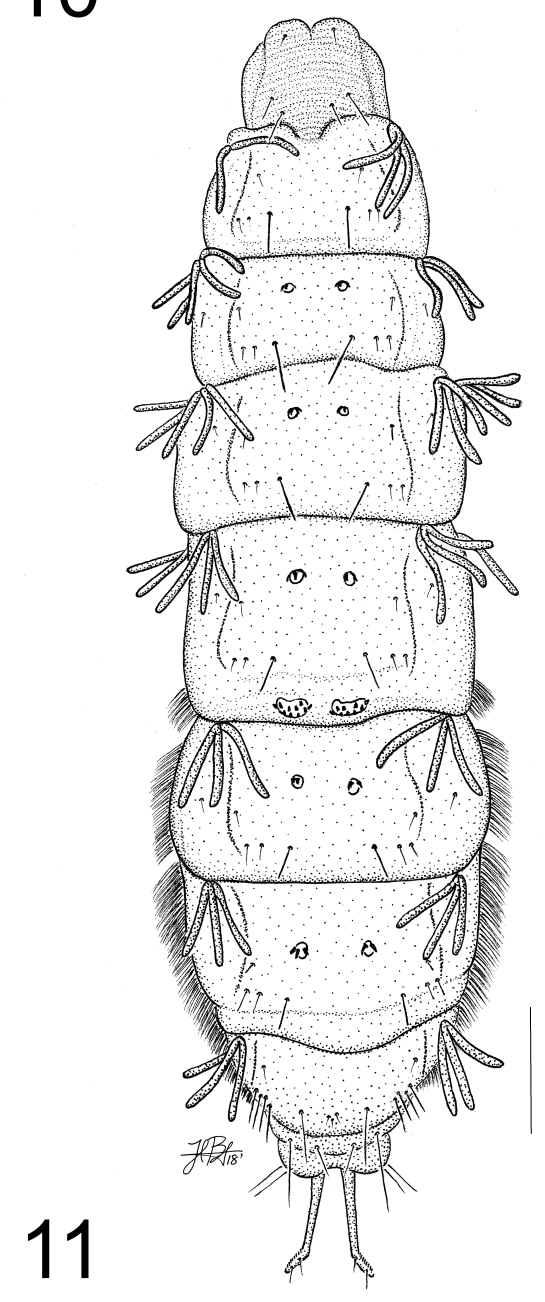

$13 \quad$ III

(1) IV

$1 \quad \mathrm{Va}$

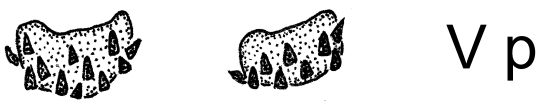

(1) VI

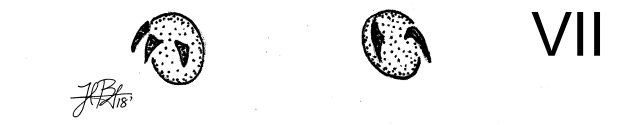

12

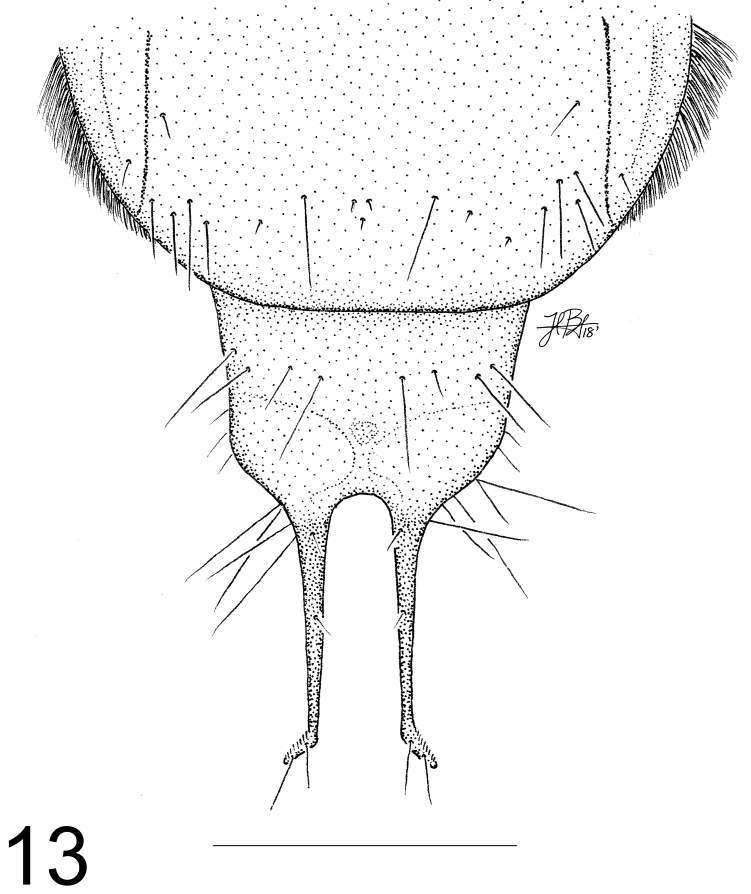

FIGURES 10-13. Limnephilus hamifer, pupa. 10, head, front; 11, abdomen, dorsal; 12, hook plates, dorsal, Roman numerals indicate numbers of abdominal segments, $\mathrm{a}=$ anterior, $\mathrm{p}=$ posterior; 13 , segment IX and anal processes, dorsal. Scale bars: 1 $\mathrm{mm}$. 


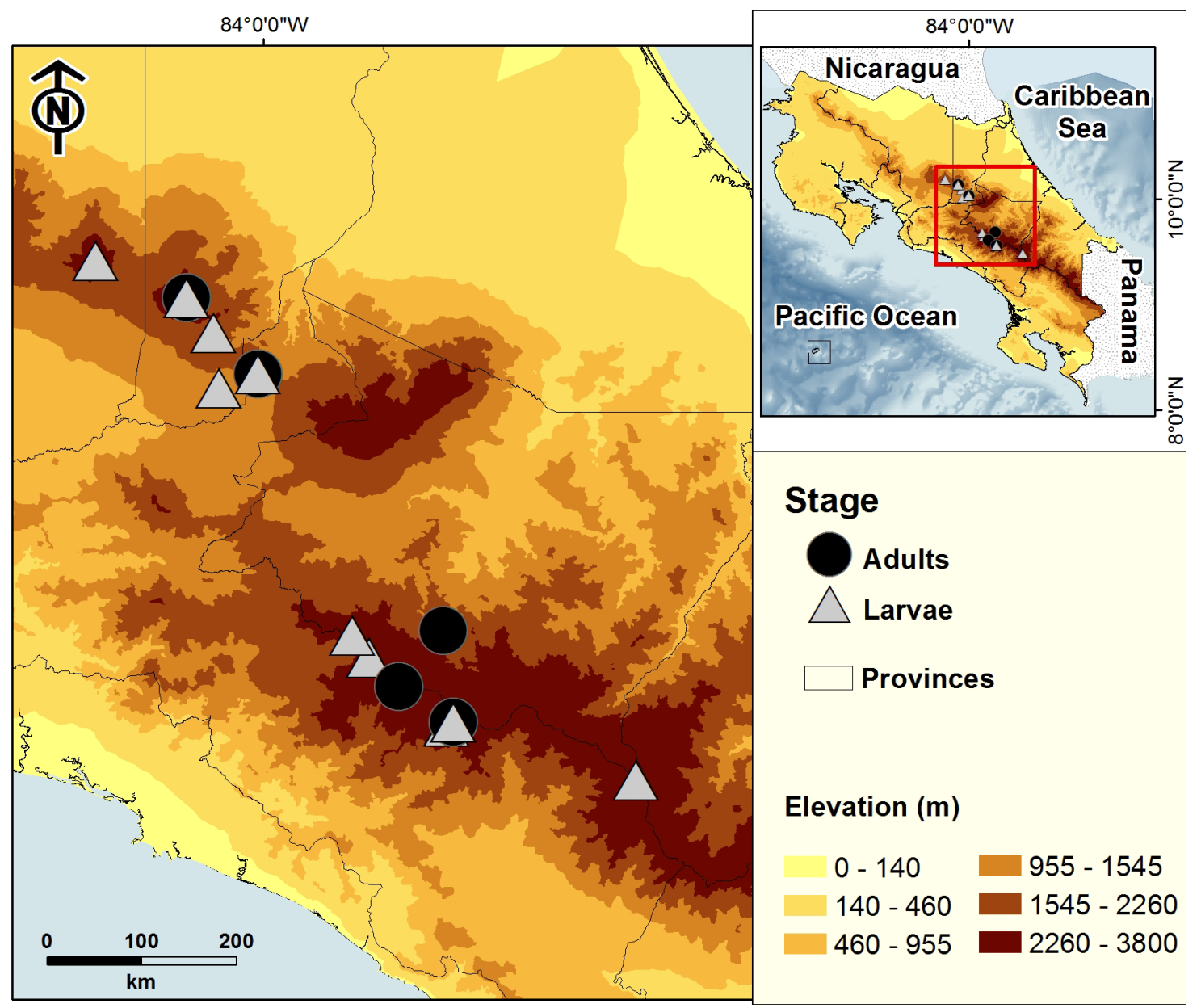

FIGURE 14. Sampling sites of larvae and adults of Limnephilus hamifer in Costa Rica. Larval collection sites from MZUCR and adult collection sites from UMSP data base.

\section{Acknowledgments}

We are most grateful to Dr. Wolfram Graf and Dr. John Morse for their very useful comments which greatly improved the quality of this publication. We thank Dr. Ralph Holzenthal and Mr. David Ruiter for providing literature and useful comments during the preparation of the manuscript. Dr. Holzenthal kindly provided distribution data from adult sampling. We are thankful to Dr. Paul Hanson for revising the English of this manuscript. The Ministry of Environment through its National System of Conservation Areas (MINAE-SINAC) provided collecting permits and the Solano family permitted access to their property where most larvae were collected.

\section{References}

Armitage, B.J., Harris, S.C. \& Holzenthal, R.W. (2015) The Trichoptera of Panama. I. New records for caddisflies (Insecta: Trichoptera) from the Republic of Panama. Insecta Mundi, 435, 1-10.

Flint, O.S. Jr. (1963) The species of Limnephilidae from Central America and Haiti (Trichoptera: Limnephilidae). Proceedings of the Entomological Society of Washington, 65, 211-213.

Flint, O.S. Jr. (1967) Studies of Neotropical caddis flies, IV: New species from Mexico and Central America. Proceedings of the United States National Museum, 123 (3608), 1-24. https://doi.org/10.5479/si.00963801.123-3608.1

Flint, O.S. Jr., Holzenthal, R.W. \& Harris, S.C. (1999) Catalog of the Neotropical caddisflies (Insecta: Trichoptera). Ohio Biological Survey, Special Publication, 1-243. 
Graf, W., Vitecek, S., Previšić, A. \& Malicky, H. (2015) New species of Limnephilidae (Insecta: Trichoptera) from Europa: Alps and Pyrenees as harbours of unknown biodiversity. Zootaxa, 3911 (3), 381-395. https://doi.org/10.11646/zootaxa.3911.3.5

Holzenthal, R.W., Blahnik, R.J., Prather, A.L. \& Kjier, K.M. (2007) Order Trichoptera Kirby, 1813 (Insecta), Caddisflies. Zootaxa, 1668, 639-689.

Holzenthal, R.W. \& Calor, A.R. (2017) Catalog of the Neotropical Trichoptera (caddisflies). Zookeys, 654, 1-566. https://doi.org/10.3897/zookeys.654.9516

Leach, W.E. (1815) Entomology. In: Brewster, D. (Ed.), The Edinburgh Encyclopedia, First Edition, 9, 52-172, pls. CCLIIICCCLV (253-360).

Lepneva, S.G. (1971) Fauna of the USSR, Trichoptera II(2). Larvae and pupae of the Integripalpia. Zoological Institute of the Academy of Science of the USSR, New Series, 95, 1-700.

Ruiter, D.E. (1995) The adult Limnephilus Leach (Trichoptera: Limnephilidae) of the New World. Bulletin of the Ohio Biological Survey, 11 (1), 1-200.

Ruiter, D.E., Boyle, E.E. \& Zhou, X. (2013) DNA barcoding facilitates associations and diagnoses for Trichoptera larvae of the Churchill (Manitoba, Canada) area. BMC Ecology, 13 (5), 1-39. https://doi.org/10.1186/1472-6785-13-5

Wallace, I.D. (1980) The identification of British limnephilid larvae (Trichoptera: Limnephilidae) which have single-filament gills. Freshwater Biology, 10, 171-189. https://doi.org/10.1111/j.1365-2427.1980.tb01191.x

Wallace, I.D., Wallace, B. \& Philipson, G.N. (2003) Keys to the case-bearing caddis larvae of Britain and Ireland. Freshwater Biological Association Scientific Publication, 61, 1-259.

Waringer, J. \& Graf, W. (2011) Atlas der mitteleuropäischen Köcherfliegenlarven-Atlas of Central European Trichoptera Larvae. Erick Mauch Verlag, Dinkelscherben, 468 pp.

Wiggins, G.B. (1996) Larvae of North American Caddisfly Genera (Trichoptera). Second Edition. University of Toronto Press, Toronto, Canada, and Buffalo, New York, 457pp. 